\title{
METRIC UNTUK MENGEVALUASI SOFTWARE BERDASARKAN PADA HASIL-HASIL EKSEKUSI KASUS
}

\author{
(MEIRICS TO EVALUATE SOFTWARE BASED ON TEST CASE EXECUTION RESULTS)
}

\author{
Diyah Puspitaningrum \\ Fakultas Teknik, Jurusan Teknologi Informasi, Universitas Semarang
}

Siti Munawaroh

Fakultas Teknologi Informasi, Universitas Stikubank

\begin{abstract}
This article describes some metrics which are used to evaluate software developed by vendors. Commonly, there are some reason why some organizations decide to use external vendor to develop their software, e.g. : their lack of ability of human resources, or they do have human resources but the project of software that is handled is complex and big. Another reason is time and practical consideration. As a case study in this article is the software project of 2000 Summer Olympics in Sydney, Australia, which its evaluations are handled by $I B M$. The project involves various components and architecture from various platforms, which is measured using complexity cyclomatic metric and metric for object oriented technology of Rational Rose. IBM also implements ODC to improve timing of feed back defect classification.
\end{abstract}

Keywords : metric, complexity cyclomatic, object of oriented, Rational Rose, ODC, defect

\section{PENDAHULUAN}

Pengembangan software terutama proyek software yang besar dan kompleks memerlukan pengukuran defect atau dikenal dengan istilah sofware metrics. Ada beberapa aiasan miengapa software metrics diperlukan :

1. Dari sudut pandang software management

Membantu mengawasi aspek provek software yang tengah berjalan, seperti kebutuhan,

penemuan perubahan

pembetulan angka dan

dan peningkatan ukuran dan kompleksitas suatu program.

2. Dari sudut pandang testing

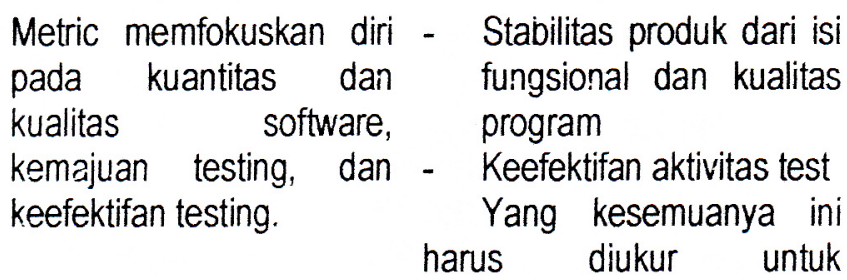

Artikel ini mengangkat menentukan sejauh mana contoh kasus proyek software tujuan yang diharapkan Olimpiade Musim Panas tahun dalam proyek yang sekarang 2000 di Sydney, Australia, ini telah tercapai.

yang pengujiannya ditangani Proyek Olimpiade Musim oleh IBM. Pembangunan Panas 2000 ini merupakan software ini mengambil salah satu peristiwa olahraga perbandingan dari event terbesar di dunia. Tabel 1 sejenis sebelumnya namun menunjukkan besarnya tentu saja terdapat tambahan- ruang lingkup data dari tambahan sesuai dengan peristiwa olahraga ini. tujuan dari proyek yang sekarang.

\section{Deskripsi Proyek}

Beberapa isu yang mengemuka adalah :

- Taksiran kemajuan proyek yang sedang dikerjakan
Fokus pada paper ini adalah pada pengembangan dan pengujian dari komponen-komponen hasil uji yang dikembangkan oleh vendor: 